\title{
Ant-nest corrosion of copper tubing in air-conditioning units*
}

\author{
D. M. Bastidas**, I. Cayuela** and J. M. Bastidas***
}

Abstract

Ant-nest corrosion is a specific type of premature failure (2-3 months) of copper tubes used in air-conditioning units causing the loss of refrigerant liquid and the consequent environment pollution. It is known that attack requires the simultaneous presence of moisture, oxygen and a corrodent, usually an organic acid, such as formic, acetic, propionic or butyric acid or other volatile organic substances like methanol, ethanol, formaldehyde or acetoaldehyde. Approximately 10\% of all premature failures of copper tubes used in the heating, ventilation and air-conditioning (HVAC) industry are the result of ant-nest corrosion. This type of corrosion usually occurs in thin-wall copper pipes, especially when copper is de-sulphurised, and is known by several names: formicary corrosion, unusual corrosion, branched pits, pinhole corrosion, etc.

Keywords Ant-nest corrosion. Copper tubes. Air-conditioning units. Organic acid vapours.

\section{Corrosión por nido de hormigas de tubos de cobre utilizados en sistemas de aire acondicionado}

\begin{abstract}
Resumen Corrosión por "nido de hormigas" es un tipo específico de fallo prematuro (2-3 meses) que tiene lugar en tubos de cobre utilizados en sistemas de aire acondicionado originando la pérdida de líquido refrigerante y la consecuente contaminación ambiental. Es conocido que este tipo de ataque requiere la presencia simultánea de humedad, oxígeno y un medio agresivo, habitualmente un ácido orgánico, como fórmico, acético, propiónico o butírico u otras sustancias orgánicas volátiles tales como metanol, etanol, formaldehido o acetoaldehido. Aproximadamente el 10\% de los fallos prematuros en tubos de cobre utilizados en calefacción, ventilación y en la industria de aire acondicionado son el resultado de corrosión por nido de hormigas. Frecuentemente, este tipo de corrosión tiene lugar en tubos de cobre de pared delgada, especialmente cuando el cobre es del tipo desulfurizado, y se conoce con varios nombres: corrosión por ácido fórmico, corrosión no habitual, picaduras ramificadas, corrosión con forma de alfiler, etc.
\end{abstract}

Palabras clave Corrosión por nido de bormigas. Tubos de cobre. Sistemas de aire acondicionado. Vapores de ácidos orgánicos.

\section{INTRODUCTION}

In air-conditioning applications, premature failure of copper tubing frequently occurs due to pitting corrosion after a short period in service (2-3 months) and even during post-installation leakage tests or during degreasing and stamping processes. This unusual type of localised corrosion in thin-walled tubes has been described in the bibliography as ant-nest (formicary) corrosion $^{[1-8]}$.

\footnotetext{
* Trabajo invitado, recibido el día 18 de septiembre de 2006 y aceptado en su forma final el día 18 de septiembre de 2006.

** CENIM-National Centre for Metallurgical Research, CSIC, Avda. Gregorio del Amo 8, 28040 Madrid, Spain E-mail address: david.bastidas@cenim.csic.es.
} 


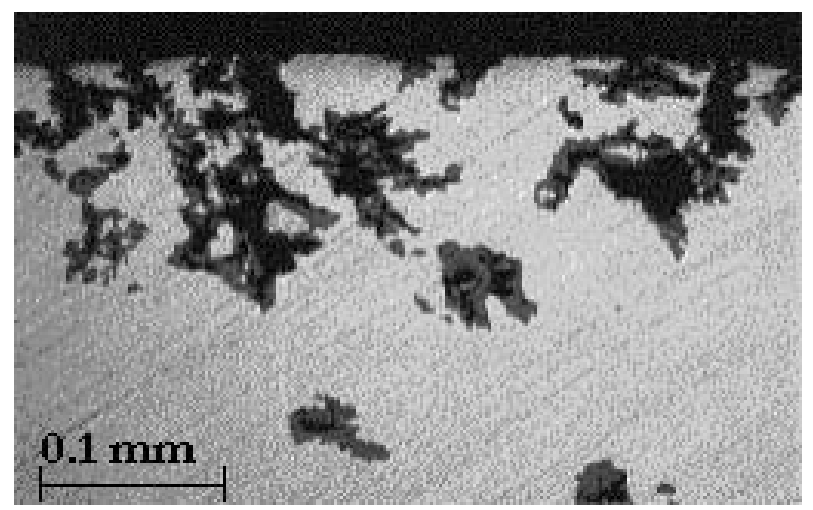

Figure 1. Cross section of copper tubes exposed to humid air containing a small amount of formic acid for four months.

Figura 1. Sección transversal de tubos de cobre expuestos a ambiente húmedo conteniendo una pequeña cantidad de ácido fórmico durante cuatro meses.

Copper tubes that suffer this type of corrosion are mainly used in heat-transfer units such as evaporators, air-conditioners, refrigerators, condensers, radiators and solar-systems ${ }^{[9-11]}$. The morphology of this corrosion is characterised by the development of longitudinal pits that form by interconnecting random microcavern channels containing porous copper oxide. Microscopic tunnels usually start on the surface of the copper tubing and progress into the tube wall. Perforation normally occurs within weeks or months, and not years. During the corrosion process, copper oxide is deposited on the inside walls of the tunnels, causing them to turn black. The corrosion pits grow from micropits that appear near the surface and their direction is not necessary confined to the direction of gravitation. The internal caverns are filled with porous cuprite $\left(\mathrm{Cu}_{2} \mathrm{O}\right)$, with voids being found at their centres.

It has been suggested that this type of corrosion may be caused by the decomposition products of chlorinated organic solvents used in degreasing, cleaning and picking treatments of the copper tubes during manufacturing or joining processes, or by certain types of synthetic lubricant oils used during the copper tubing stamping process ${ }^{[1-8,11 \text { and } 12]}$. These copper oxide deposits serve as a nutrient for the decomposition process by providing oxygen for chemical reactions to take place. In these studies, carboxylic acids were formed by the oxidation of the respective alkyladehyde vapours (see Fig. 1).

In some cases, carboxylic acids may be the corrosive media, because formic and acetic acids are detected in the atmosphere where the copper tubes are placed. Experiments produce similar corrosion when copper tubes are exposed to a humid oxygen atmosphere containing small amounts of carboxylic acids, such as formic, acetic, propionic or butyric acid, for a few months ${ }^{[13]}$.

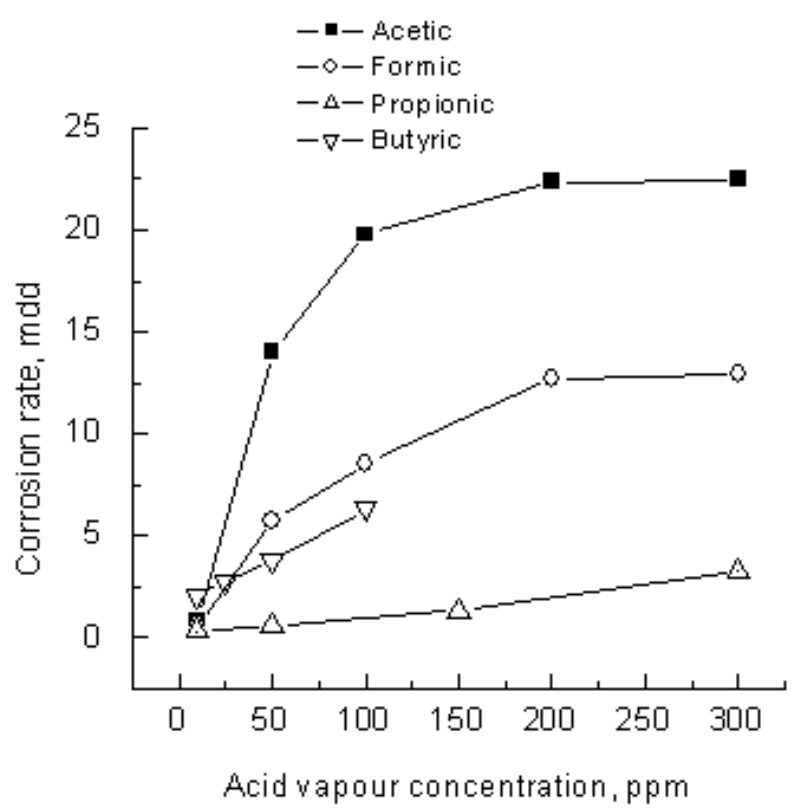

Figure 2. Copper corrosion rate estimated from gravimetric data $\left(\mathrm{mg} / \mathrm{dm}^{2} \mathrm{~d}\right.$, mdd) for formic, acetic, propionic and butyric acids, after 21 days of experimentation at $100 \%$ relative humidity and $30^{\circ} \mathrm{C}$ temperature.

Figura 2. Velocidad de corrosión del cobre estimada mediante medidas gravimétricas ( $\mathrm{mg} / \mathrm{dm}^{2}$ día, $\mathrm{mdd}$ ) en presencia de los ácidos fórmico, acético, propiónico y butírico, después de 21 dias de experimentación a humedad relativa del 100\% y $30{ }^{\circ} \mathrm{C}$ de temperatura.

Ant-nest corrosion was first reported in the early 1970s by Edwards et al. in Canada ${ }^{[9]}$. Leakage failure due to formicary corrosion was observed in phosphorous-deoxidised copper tubes incorporated in refrigerators and air-conditioners, and the corrosion was considered to be initiated by the presence of a production environment involving the coexistence of organic solvents and water. As the corrosion-promoting substances, the authors identified the composition products of chlorine-based organic solvents, i.e. hydrochloric acid and phosgene $\left(\mathrm{COCl}_{2}\right)$, used as agents for the degreasing and washing of copper tubes.

In n-pentanoic acid $\left(\mathrm{C}_{4} \mathrm{H}_{9} \mathrm{COOH}\right)$ and octannic acid $\left(\mathrm{C}_{7} \mathrm{H}_{15} \mathrm{COOH}\right)$, however, green-coloured thin films showing good adhesion to the surface were formed. No local corrosion was found under these films.

Volatile organic substances are produced by many everyday substances, such as vinegar-containing seasonings like vegetable oil dressing and grain vinegar, cosmetics such as eau de cologne, adhesives in synthetic building materials, insecticides, woods and certain paints, plastics, rubbers and resins, all of which are suspected to cause the deterioration of copper. Organic acid anions constitute about 0.1 to $1 \%$ of the total ion concentration in the corrosion products (patina) on 

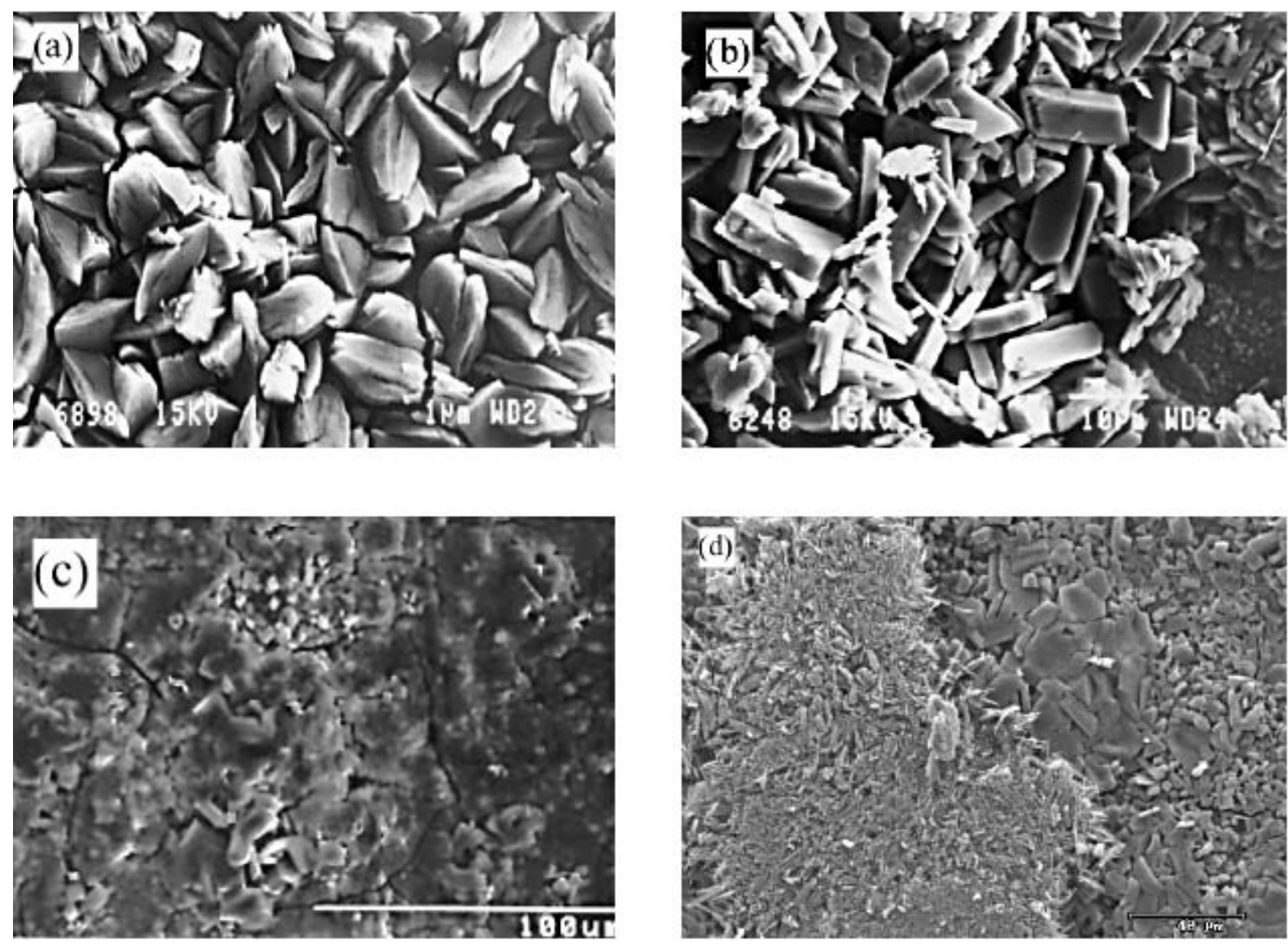

Figure 3. SEM micrographs for copper exposed to 100 ppm of (a) formic acid, (b) acetic acid, (c) propionic acid, and (d) butyric acid, after 21 days of experimentation at $100 \%$ relative humidity and $30{ }^{\circ} \mathrm{C}$ temperature.

Figura 3. Micrografías de SEM de cobre expuesto a 100 ppm de (a) ácido fórmico, (b) ácido acético, (c) ácido propiónico, y (d) ácido butírico, después de 21 días de experimentación a humedad relativa del $100 \%$ y $30^{\circ} \mathrm{C}$ de temperatura.

copper exposed to outdoor atmospheres for long periods ${ }^{[4}$ and 14-16].

The aim of this paper is to review the bibliography in this area, describing copper corrosion originated by carboxylic organic acid in simulated environments; the sources of organic acid emissions and generation; and the current state of knowledge on the mechanism of initiation of copper ant-nest corrosion.

\section{VAPOUR PHASE CORROSION OF COPPER IN SIMULATED ENVIRONMENTS}

Fig. 2 shows the corrosion rate of copper exposed to formic $(\mathrm{HCOOH})$, acetic $\left(\mathrm{CH}_{3} \mathrm{COOH}\right)$, propionic $\left(\mathrm{CH}_{3} \mathrm{CH}_{2} \mathrm{COOH}\right)$ and butyric $\left(\mathrm{CH}_{3}\left(\mathrm{CH}_{2}\right)_{2} \mathrm{COOH}\right)$ organic acid vapours after 21 days, in $\mathrm{mg} / \mathrm{dm}^{2} \mathrm{~d}$ (mdd), at $100 \%$ relative humidity $(\mathrm{RH})$ and at $25^{\circ} \mathrm{C}$ temperature. The corrosion rate increases with the vapour concentration. The highest corrosion is yielded by acetic acid ( $\sim 23$ mdd), followed by formic, butyric and propionic. Considering their dissociation constants in aqueous solution at $25^{\circ} \mathrm{C}$ temperature $\left(1.77 \times 10^{-4}\right.$ for formic acid; $1.76 \times 10^{-5}$ for acetic acid; $1.34 \times 10^{-5}$ for propionic acid; and $1.54 \times 10^{-5}$ for butyric acid), a direct relationship can be seen between the acidity of the vapours and the corrosion rate, except in the case of formic acid. In this case, the lower corrosion rate can be explained on the grounds of a more protective character of the corrosion products formed when copper is exposed to formic vapours, compared with the porous nature of the corrosion products formed upon exposure to the other acids ${ }^{[17-20]}$.

Fig. 3 shows SEM (scanning electron microscopy) micrographs for copper specimens exposed to 100 ppm (parts per million) of (a) formic acid, (b) acetic acid, (c) propionic acid, and (d) butyric acid. In all cases the corrosion products cover almost the entirety of the copper surface. However, the aspect of the layer formed is different, being more homogeneous and 


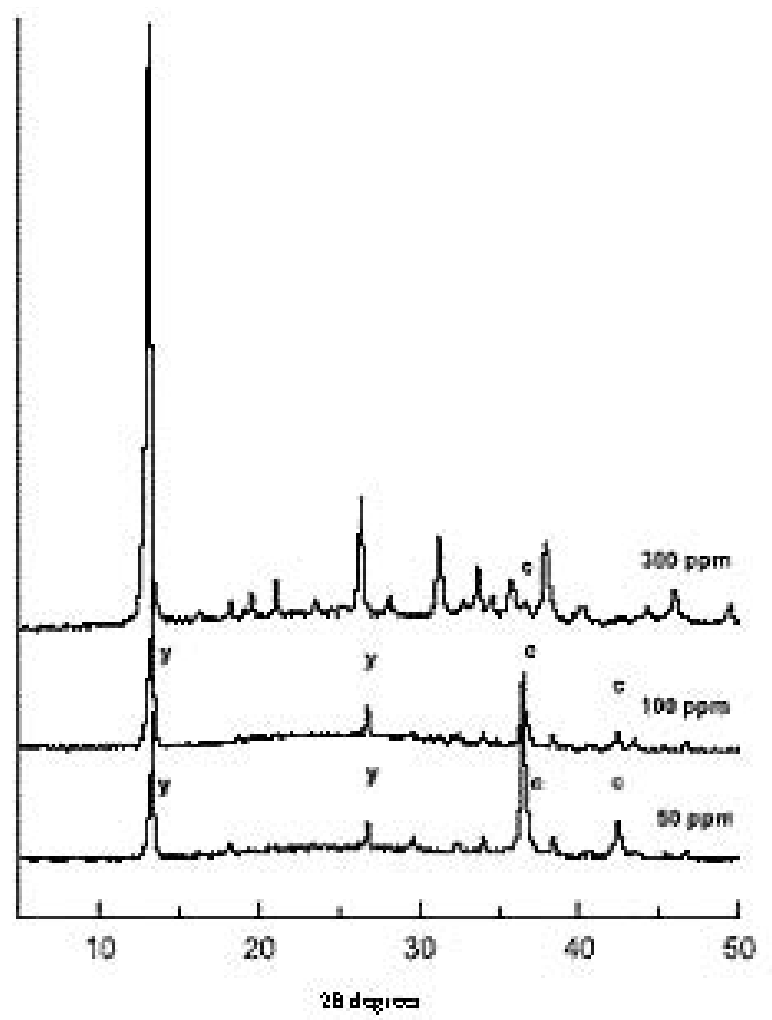

Figure 4. XRD patterns for copper specimens exposed to 50, 100 and 300 ppm of formic acid, after 21 days of experimentation at $100 \%$ relative humidity and $30{ }^{\circ} \mathrm{C}$ temperature. The identified compounds are, (c) cuprite, (y) copper hydroxide, and (unidentified peaks) copper formiate.

Figura 4. Muestras de XRD de cobre expuesto a 50, 100 y 300 ppm de ácido fórmico, después de 21 días de experimentación a humedad relativa del $100 \%$ y $30^{\circ} \mathrm{C}$ de temperatura. Los compuestos identificados son, (c) cuprita, (y) hidróxido de cobre, y (picos sin identificar) formiato de cobre.

compact for formic and propionic acids than for acetic and butyric, with the appearance of crystal aggregates of a different morphology and a larger size in the former case. This more compact layer in the case of formic acid may impede the corrosion process and may be responsible for the lower corrosion rate determined using the gravimetric method.

Fig. 4 shows representative XRD (X-ray diffraction) patterns recorded from 5 to $502 \theta$ degrees for copper specimens exposed to the action of formic acid vapours (50, 100 and $300 \mathrm{ppm}$ ) at 100\% RH for 21 days experimentation. The patterns for copper exposed to 50 and $100 \mathrm{ppm}$ of formic acid show the presence of hydrated copper hydroxide $\left(\mathrm{Cu}(\mathrm{OH})_{2} \cdot \mathrm{H}_{2} \mathrm{O}\right)$ and cuprite. A third not completely crystalline phase also starts to form. This phase may be attributed to a copper hydroxyformate $(\mathrm{Cu}(\mathrm{OH})(\mathrm{HCOO}))$ which is formed as an intermediate product. At 300 ppm the main component of the patina is copper formate $\left(\mathrm{Cu}(\mathrm{HCOO})_{2}\right)$. The peaks corresponding to cuprite

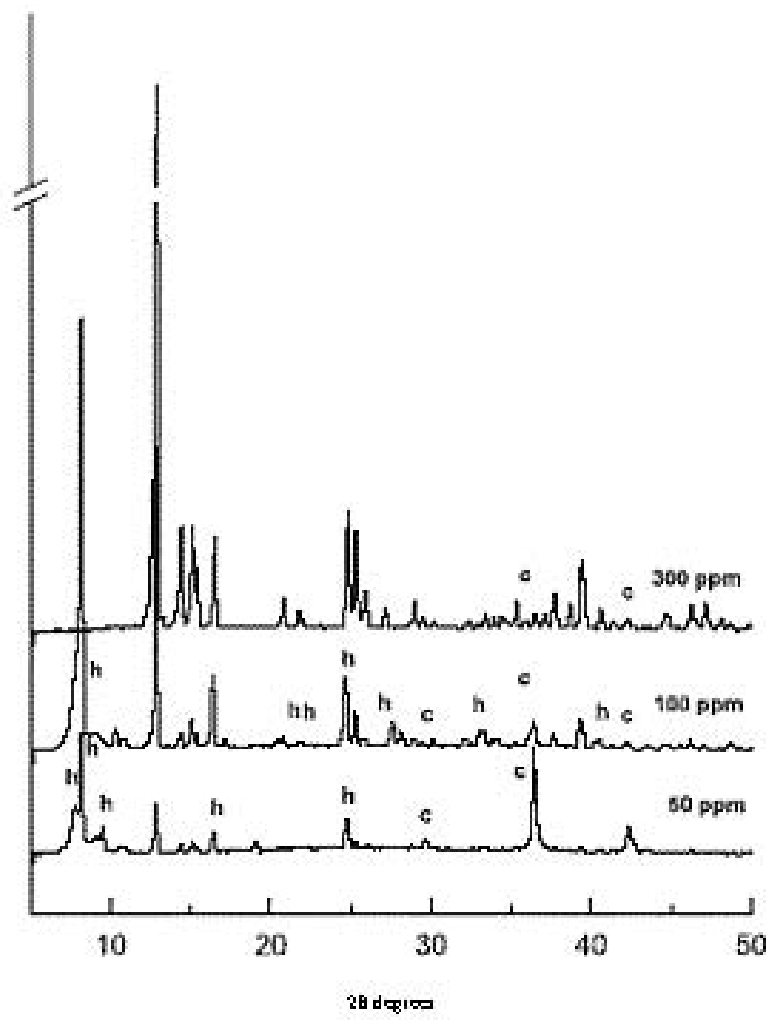

Figure 5. XRD patterns for copper specimens exposed to 50, 100 and 300 ppm of acetic acid, after 21 days of experimentation at $100 \%$ relative humidity and $30^{\circ} \mathrm{C}$ temperature. The identified compounds are, (c) cuprite, (h) copper hydroxideacetate, and (unidentified peaks) copper acetate.

Figura 5. Muestras de XRD de cobre expuesto a 50, 100 y 300 ppm de ácido acético, después de 21 días de experimentación a humedad relativa del $100 \%$ y $30^{\circ} \mathrm{C}$ de temperatura. Los compuestos identificados son, (c) cuprita, (h) hidroxiacetato de cobre, $y$ (picos sin identificar) acetato de cobre.

decrease with the increase in the vapour formic acid concentration from 100 to $300 \mathrm{ppm}$. At the same time the copper hydroxide decreases, and at $300 \mathrm{ppm}$ this peak is almost not observed in the pattern.

Fig. 5 shows XRD patterns recorded from 5 to $502 \theta$ degrees for copper specimens exposed to the action of acetic acid vapours (50, 100 and $300 \mathrm{ppm}$ ) at 100\% RH for 21 days experimentation. The patterns for copper exposed to 50 and 100 ppm of acetic acid show the presence of cuprite and dihydrated copper acetate $\left(\mathrm{Cu}\left(\mathrm{CH}_{3} \mathrm{COO}\right)_{2} \cdot 2 \mathrm{H}_{2} \mathrm{O}\right)$, besides a third phase attributed to a copper hydroxyacetate $\left(\mathrm{Cu}(\mathrm{OH})\left(\mathrm{CH}_{3} \mathrm{COO}\right)_{2} \cdot 2 \mathrm{H}_{2} \mathrm{O}\right)$ which is formed as an intermediate product. At $300 \mathrm{ppm}$ the main components of the patina are cuprite and copper acetate $\left(\mathrm{Cu}\left(\mathrm{CH}_{3} \mathrm{COO}\right)_{2}\right)$.

Fig. 6 shows representative XRD patterns recorded from 5 to $502 \theta$ degrees for copper specimens exposed to the action of propionic acid vapours (10, 50, 150 and $300 \mathrm{ppm}$ ) at 100\% RH for 21 days experimentation. The patterns were obtained by direct analysis of 


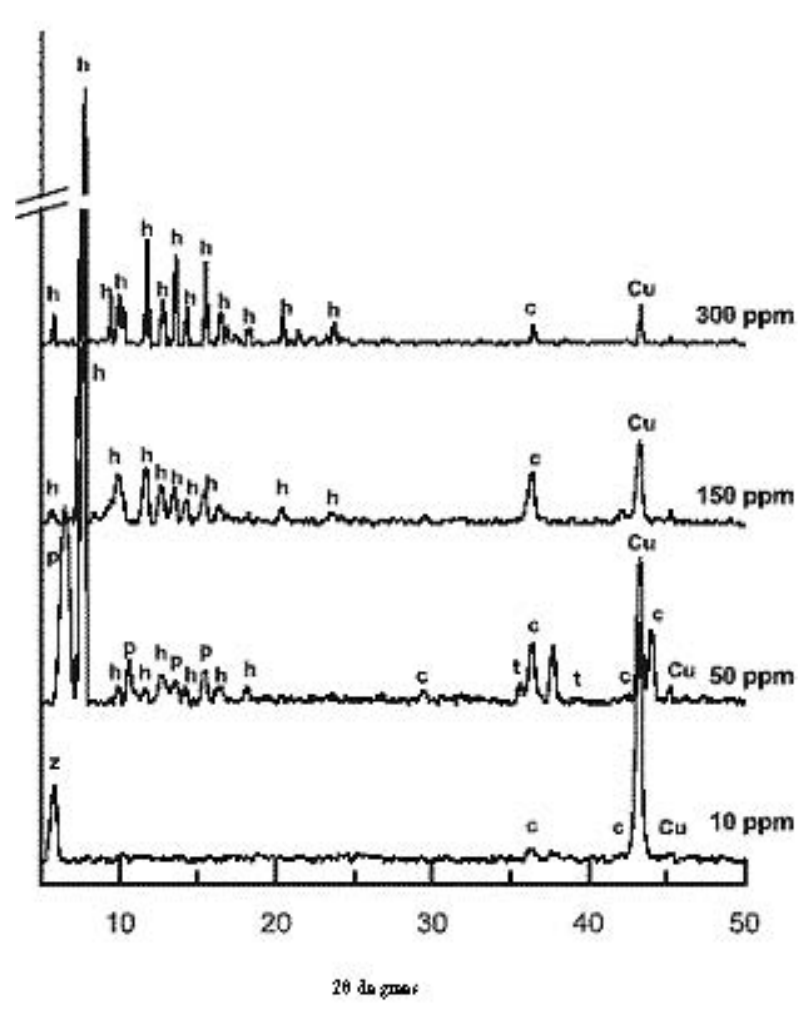

Figure 6. XRD patterns for copper specimens exposed to 10 , 50,150 and 300 ppm of propionic acid, after 21 days of experimentation at $100 \%$ relative humidity and $30^{\circ} \mathrm{C}$ temperature. The identified compounds are, (Cu) metallic copper, (c) cuprite, (t) tenorite, (p) copper propionate, and (h), (z) two unidentified phases.

Figura 6. Muestras de XRD de cobre expuesto a 10, 50, 150 y 300 ppm de ácido propiónico, después de 21 días de experimentación a humedad relativa del $100 \%$ y $30{ }^{\circ} \mathrm{C}$ de temperatura. Los compuestos identificados son, (Cu) cobre metálico, (c) cuprita, (t) tenorita, (p) propionato de cobre, y (h), (z) dos fases sin identificar.

the copper specimens. At 10 ppm the presence of only cuprite is observed (besides metallic copper) along with an unidentified organic compound at low diffraction angles. At 50 ppm weak peaks appears which are attributed to tenorite $(\mathrm{CuO})$. As the propionic acid concentration increases, so the crystallinity of cuprite increases, and copper propionate $\left(\mathrm{Cu}\left(\mathrm{CH}_{3} \mathrm{CH}_{2} \mathrm{COO}\right)_{2}\right)$ appears, along with another unidentified organic compound, which is the main compound at $300 \mathrm{ppm}$.

Fig. 7 shows XRD patterns recorded from 5 to 50 $2 \theta$ degrees for copper specimens exposed to the action of butyric acid vapours (5, 25 and $100 \mathrm{ppm})$ at $100 \% \mathrm{RH}$ for 21 days experimentation. With the smallest concentration ( 5 ppm), besides cuprite and metallic copper, peaks appear at low diffraction angles corresponding to copper butyrate $\left(\mathrm{Cu}\left(\mathrm{CH}_{3}\left(\mathrm{CH}_{2}\right)_{2} \mathrm{COO}\right)_{2}\right)$. As the butyric acid concentration increases, so the formation of cuprite decreases and at the same time the

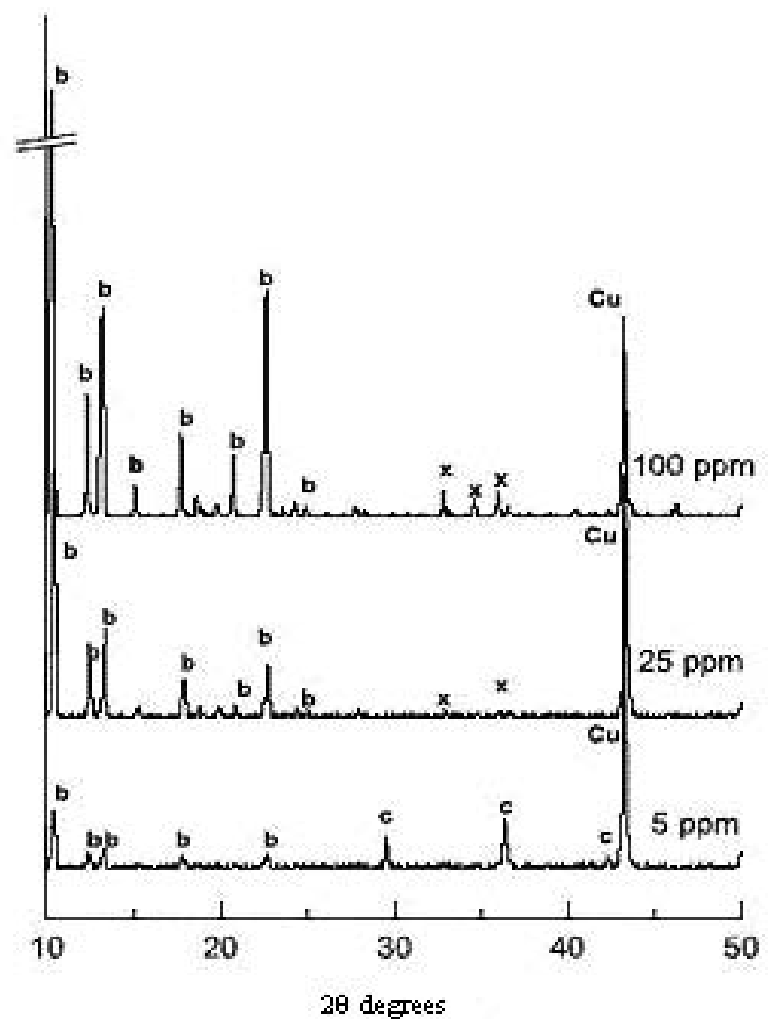

Figure 7. XRD patterns for copper specimens exposed to 5 , 25 and 100 ppm of butyric acid, after 21 days of experimentation at $100 \%$ relative humidity and $30{ }^{\circ} \mathrm{C}$ temperature. The identified compounds are, (Cu) metallic copper, (c) cuprite, (b) copper butirate, and ( $\mathrm{x}$ ) unidentified phase.

Figura 7. Muestras de XRD de cobre expuesto a 5, 25 y 300 ppm de ácido butírico, después de 21 días de experimentación a humedad relativa del $100 \%$ y $30^{\circ} \mathrm{C}$ de temperatura. Los compuestos identificados son, (Cu) cobre metálico, (c) cuprita, (b) butirato de cobre, $y(x)$ fases sin identificar.

copper butyrate level increases. Besides, a new phase with a maximum diffraction at $35^{\circ}$ appears. This compound may correspond to the acicular crystals observed by SEM (see Fig. 3d). In these cases cuprite has been identified, along with the ethers corresponding to the different acids: copper formate, copper acetate, copper propionate and copper butyrate. In some cases intermediate compounds appear, like copper hydroxide $\left(\mathrm{Cu}(\mathrm{OH})_{2}\right)$ or copper hydroxyacetate. Copper oxides and hydroxides predominate at the lowest concentrations, and as the vapour concentrations increase the presence of ether becomes more significant.

The corrosion of copper exposed to organic acid vapours can be explained as follows. When copper is exposed to $100 \% \mathrm{RH}$ it corrodes in local areas of the surface, forming an initial layer of cuprite. This process can be catalysed by acid vapours according to the following reaction ${ }^{[17-30]}$ :

$$
4 \mathrm{Cu}+\mathrm{O}_{2}+4 \mathrm{H}^{+} \rightarrow 4 \mathrm{Cu}^{+}+2 \mathrm{H}_{2} \mathrm{O}
$$


$\mathrm{Cu}^{+}$will subsequently oxidise:

$$
4 \mathrm{Cu}^{+}+\mathrm{O}_{2}+4 \mathrm{H}^{+} \rightarrow 4 \mathrm{Cu}^{2+}+2 \mathrm{H}_{2} \mathrm{O}
$$

forming tenorite and dihydrated copper hydroxide $\left(\mathrm{Cu}(\mathrm{OH})_{2} \cdot 2 \mathrm{H}_{2} \mathrm{O}\right)$; by reaction with the hydroxyl ions $\left(\mathrm{OH}^{-}\right)$produced in the cathodic reaction. The patina formed on the copper surface is known to have a duplex structure, with the cuprite as the inner layer and oxides/hydroxides as the outer layer ${ }^{[23]}$. The esters corresponding to each acid will subsequently form by the reaction of the acids with the copper hydroxide. For instance, in the case of butyric acid the reaction is:

$$
\begin{gathered}
\mathrm{Cu}(\mathrm{OH})_{2} \cdot \mathrm{H}_{2} \mathrm{O}+2 \mathrm{CH}_{3}\left(\mathrm{CH}_{2}\right)_{2} \mathrm{COOH} \rightarrow \\
\mathrm{Cu}\left(\mathrm{CH}_{3}\left(\mathrm{CH}_{2}\right)_{2} \mathrm{COO}\right)_{2}+3 \mathrm{H}_{2} \mathrm{O}
\end{gathered}
$$

In the case of acetic acid the following mechanism has been proposed for the patina formation on copper. In atmospheres with a low vapour content of this acid, a basic copper acetate forms preferentially from preexisting copper oxide, according to the reaction:

$$
\begin{gathered}
4 \mathrm{Cu}(\mathrm{OH})_{2} \cdot \mathrm{H}_{2} \mathrm{O}+7 \mathrm{CH}_{3} \mathrm{COOH} \rightarrow \\
\mathrm{Cu}_{4}(\mathrm{OH})\left(\mathrm{CH}_{3} \mathrm{COO}\right)_{7} \cdot 2 \mathrm{H}_{2} \mathrm{O}+6 \mathrm{H}_{2} \mathrm{O}
\end{gathered}
$$

This copper hydroxide acetate evolves to form copper acetate in atmospheric conditions of a high acetic acid concentration, by the reaction:

$$
\begin{gathered}
\mathrm{Cu}_{4}(\mathrm{OH})\left(\mathrm{CH}_{3} \mathrm{COO}\right)_{7} \cdot 2 \mathrm{H}_{2} \mathrm{O}+\mathrm{CH}_{3} \mathrm{COOH} \rightarrow \\
4 \mathrm{Cu}\left(\mathrm{CH}_{3} \mathrm{COO}\right)_{2} \cdot 2 \mathrm{H}_{2} \mathrm{O}+\mathrm{H}_{2} \mathrm{O}
\end{gathered}
$$

On the other hand, formic acid on copper leads to the formation of copper formates ${ }^{[25]}$. At a low vapour content the hydroxide or hydrated copper(II) on the initially exposed copper surface provides a building block for the formation of an intermediate copper hydroxyformate. In this case the proposed reaction is:

$$
\begin{gathered}
\mathrm{Cu}(\mathrm{OH})_{2} \cdot \mathrm{H}_{2} \mathrm{O}+2 \mathrm{HCOOH} \rightarrow \\
\mathrm{Cu}(\mathrm{OH})(\mathrm{HCOO})+2 \mathrm{H}_{2} \mathrm{O}
\end{gathered}
$$

The copper hydroxyformate converts to copper formate on further reactions with formic acid, in a similar way to that shown in equation (5).

At a high formic acid content the proposed reactions are:

$$
\begin{gathered}
\mathrm{Cu}(\mathrm{OH})_{2} \cdot \mathrm{H}_{2} \mathrm{O}+2 \mathrm{HCOOH} \rightarrow \\
\mathrm{Cu}(\mathrm{HCOO})_{2}+3 \mathrm{H}_{2} \mathrm{O} \\
\mathrm{Cu}(\mathrm{OH})_{2} \cdot \mathrm{xH}_{2} \mathrm{O}+2 \mathrm{HCOOH} \rightarrow \\
\mathrm{Cu}_{4}(\mathrm{OH})\left(\mathrm{CH}_{3} \mathrm{COO}\right)_{7} \cdot 2 \mathrm{H}_{2} \mathrm{O}+(\mathrm{x}+1) \mathrm{H}_{2} \mathrm{O}
\end{gathered}
$$

The RH strongly affects copper corrosion. In the presence of acetic acid, the copper corrosion rate increases as the $\mathrm{RH}$ rises ${ }^{[22]}$. The main components of the patina are cuprite, copper hydroxide and copper acetate. An increase in the acetic acid content leads to a decrease in copper hydroxide and an increase in cuprite and copper acetate.

The studies of Graedel et al. ${ }^{[31]}$ and Muller and McCrory-Joy ${ }^{[32]}$, on patina specimens taken from The Statue of Liberty and compared with the products obtained on copper specimens exposed to indoor atmospheres, reveal the existence of an organic cementant among the copper compounds. According to EGA analysis (evolved gas analysis), this compound probably corresponds to a copper oxalate. According to ionic chromatography analysis of these patinas, oxides, sulphates, nitrates, chlorides, oxalates, formates and acetates were found in aqueous extracts and fatty acids and several alkenes in acetone extracts ${ }^{[33-37]}$.

In the nucleation and cementation process of the patina components, Graedel et al. ${ }^{[38 \text { and } 39]}$ proposed a sequence of three steps. In the first, the sulphate $\left(\mathrm{SO}_{4}^{2-}\right)$ and hydroxyl ions contained in the aqueous layer interact with the copper(I) ions, leading to dissolution of the metallic copper. The second step involves the oxidation of the copper(I) ion to copper(II) ion, allowing the formation of a sulphated complex with superficial copper atoms. In the third stage, two processes take place simultaneously: the bonding of a copper ion with the adsorbed surface group (and subsequently with a hydroxyl group) and the action of an organic cementant that affixes a copper ion in the vicinity of the sulphate crystal embryo. The species that constitute the organic cementant have a molecular weight of less than 200 units of atomic mass and multiple functional groups. It is likely that concentrations of more than $10^{-5} \mathrm{M}$ of these compounds may produce significant metallic bonding. It is important to note that these concentrations are within the ranges observed for the presence of carboxylic acid in rainwater. Subsequent interaction between the components that constitute the organic cementant with copper(II) and hydroxyl ions will produce the formation of sulphated phases, among them brochantite $\left(\mathrm{Cu}_{4}\left(\mathrm{SO}_{4}\right)(\mathrm{OH})_{6}\right)$.

Nassau et al. ${ }^{[40]}$ proposes that since organic acids are moderately soluble in water, they tend to precipitate in the preexisting patina, explaining the relatively high of oxalates contents found in copper specimens. Copper specimens exposed to indoor atmospheres in Sweden and Czechoslovakia and analysed by XPS (Xray photoelectron spectroscopy) and IRAS (infrared reflection-absorption spectroscopy) reveal the existence of an important amount of copper carboxylate and, in smaller amounts, sulphates, chlorides $\left(\mathrm{Cl}^{-}\right)$, nitrates $\left(\mathrm{NO}_{3}^{-}\right)$and ammonium $\left(\mathrm{NH}_{4}^{+}\right)$within the following compositional ranges: carbon-oxygen compounds (including carbonates) $\mathrm{CO}_{\mathrm{x}}$ (10 to $14 \%$ ), chlorides $(0.4$ to $3.2 \%)$, sulphates $(0.3$ to $0.7 \%)$, nitrates (0.7 to $1 \%)$ and ammonium $(0.4 \text { to } 0.9 \%)^{[41]}$. The re- 


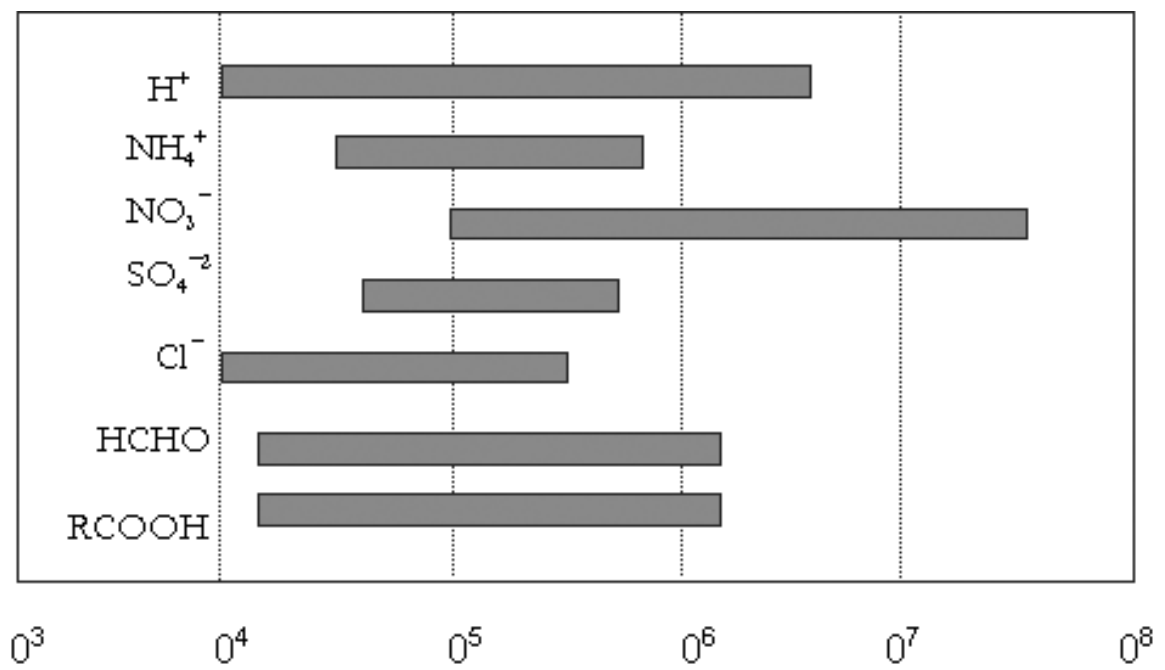

Annual total exposure, $\mu$ eq-h/year

Figure 8. Annual total of atmospheric pollutants over the cities of Los Angeles, Saint Paul and New York, including all regimes of dew, snow, rain and fog ${ }^{[39]}$.

Figura 8. Contaminación atmosférica total anual en las ciudades de Los Angeles, San Pablo y Nueva York, incluyendo todas las formas de rocío, nieve, lluvia y niebla[39].

sults found with copper specimens are similar to those obtained with nickel or zinc specimens.

From the study of Peerson and Leygraf the following mechanism for the formation of organic compounds can be proposed ${ }^{[41]}$. The organic species in the air or in aerosols (organic aldehydes, acids, volatile compounds) are transported towards the surface of the metal and consequently into the superficial aqueous monolayers. These species can undergo oxidation in these monolayers in the presence of oxidants, light, radicals and other reactants. The formed species of carboxylates in these monolayers interact with the hydrated superficial oxide. The proton ions $\left(\mathrm{H}^{+}\right)$of the acid interact with the hydroxyl groups, weaken the superficial Me-O bonding, and expose the superficial metallic ions. These ions can be coordinated with the carboxylate ions, which separate from the superficial oxide and move towards more favourable sites. Thereafter, a thin layer of metal carboxylate tends to precipitate, incorporating a water or a hydroxyl group.

\section{CARBOXYLIC ACIDS IN DIFFERENT ENVIRONMENTS}

Metallic atmospheric corrosion is due to deposition of the pollutants found in the different phases of the atmosphere (especially in clouds, aerosols, rain and fog) on the metallic surface, reacting with the substrate and leading to corrosion. Those pollutants are either organic or inorganic. The inorganic pollutants found in the atmosphere include $\mathrm{NO}_{2}, \mathrm{SO}_{2}, \mathrm{NH}_{3}, \mathrm{HCl}, \mathrm{CO}_{2}$ and $\mathrm{O}_{3}$. The organic compounds in the atmosphere, also known as volatile organic compounds (VOC), are several hydrocarbons and vapours of organic acids such as formic, acetic, propionic and butyric. In general, most pollutants contribute to the total acidity of rainwater in urban areas and it is estimated that the contribution of organic acids is about $35 \%$ of the total. VOC emissions can be either anthropogenic or biogenic. The average contents measured in the atmosphere for formic, acetic and propionic acids are about 8, 9 and 0.3 ppb (parts per billion), respectively.

\subsection{Carboxylic acids in natural environments}

Carboxylic acids of low molecular weight, such as formic, acetic, propionic and butyric acids, as well as other acids (n-pentanoic, hexanoic, heptanoic, etc.), are present in rain, snow, clouds and particulate mat-

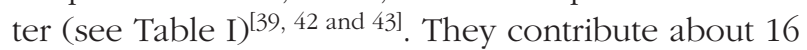
to $36 \%$ of rain acidity ${ }^{[44]}$. It is estimated that nearly $64 \%$ of formic acid and about $88 \%$ of acetic acid are in the vapour phase $\mathrm{e}^{[22}$ and $\left.45-51\right]$.

The lowest vapour phase concentrations of formic and acetic acids (and probably also propionic) are typical of well conserved forest areas and their presence is related to the oxidation of reactive hydrocarbons, biogenic in origin, such as isoprene ${ }^{[52]}$. 
Table I. Content of low molecular weight carboxylic acid in various phases in the atmosphere.

Tabla I. Contenido de ácidos carboxílicos de bajo peso molecular en varias fases en la atmósfera.

\begin{tabular}{cccc}
\hline Event & Formic acid & Acetic acid & Propionic acid \\
\hline Rain & $0.4-40 \mu \mathrm{M}$ & $0.4-31 \mu \mathrm{M}$ & - \\
& $33 \mu \mathrm{M}^{[39]}$ & $1-10 \mu \mathrm{M}^{[39]}$ & $0.1-0.6 \mathrm{ppb}^{[42} \mathrm{and}^{43]}$ \\
Snow & $0.01-13 \mathrm{ppb}$ & $0.03-16 \mathrm{ppb}$ & - \\
Fog & $6 \mu \mathrm{M}^{[39]}$ & $3 \mu \mathrm{M}^{[39]}$ & - \\
Aerosol & $92 \mu \mathrm{M}^{[39]}$ & $43 \mu \mathrm{M}^{[39]}$ & - \\
Reference & $0.01-1.24 \mathrm{mg} / \mathrm{m}^{3}$ & $0.07-0.996 \mathrm{mg} / \mathrm{m}^{3}$ & {$[42,43]$} \\
\hline
\end{tabular}

Semi-urban environments can contain about 0.8 to $1.0 \mathrm{ppb}$ of acetic acid and 0.6 to $3.4 \mathrm{ppb}$ of formic acid, related to biogenic emissions ${ }^{[53]}$. In similar areas during intensive solar activity, concentration values of both acids of about $2.5 \mathrm{ppb}$ have been found ${ }^{[42}$ and 54$]$.

Rural areas show concentrations from 0.6 to 15.0 $\mathrm{ppb}$ for both acetic and formic acids, whose formation is related to direct emission and anthropogenic hydrocarbon oxidation. Concentrations of about 0.5-8.1 ppb and 0.6-9.5 ppb for acetic and formic acids, respectively, have been found at Sao Paulo (Brazil) ${ }^{[44]}$. Midday concentrations for this city were nearly 200\% higher than those recorded during night-time hours. Similar variations have been reported by Puxbaum et al. for different carboxylic acids ${ }^{[55]}$.

During an event of photochemical smog in Los Angeles, California, the measured carboxylic acids concentrations $\left(\mathrm{C}_{2}-\mathrm{C}_{10}\right)$ were 10 to 50 times higher than those found in rural areas ${ }^{[43]}$. Acetic acid was measured at about $6.6 \mathrm{ppb}\left(16.1 \mu \mathrm{g} / \mathrm{m}^{3}\right)$ and propionic acid at about $0.55 \mathrm{ppb}\left(1.67 \mu \mathrm{g} / \mathrm{m}^{3}\right)$.

Carboxylic acid (formic and acetic) rain concentrations range from 1.0 to $5.8 \mu \mathrm{M}$ for marine environments, 4.0 to $17.9 \mu \mathrm{M}$ for remote areas (Australia, Amazonia, Venezuela), 0.6 to $9.3 \mu \mathrm{M}$ for rural areas and 7.9 to $12.4 \mathrm{mM}$ for urban areas. A study carried out in the cities of Los Angeles (Cal.), Saint Paul (Minn.) and New York, revealed that total emissions of carboxylic acids were of the same order as other pollutants, when comparing total depositions and taking into account the different forms of atmospheric preci-

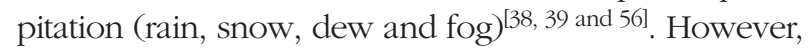
these emissions were quite low compared with total depositions of nitrate species (see Fig. 8).

Andreae et al. ${ }^{[52]}$ and Puxbaum et al. ${ }^{[55]}$ studied precipitation events in which formic and acetic acids were responsible for up to $65 \%$ of the acidity measured in remote regions, and estimated that these acids may contribute up to $35 \%$ of the acidity in highly industrialised areas.

\subsection{Biogenic emissions}

Carboxylic acids are produced by the combustion of biomass, and analyses of the smoke from fire events reveal concentrations of about 300 to $500 \mathrm{ppb}$ for formic acid and 3000 to 5000 ppb for acetic acid. They can also be generated by natural emissions resulting from biological processes, as shown by the data in Table II for two tropical sites ${ }^{[50}$ and 52].

The hydrolysis of hemicellulose, the main constituent of wood, produces important amounts of acetic acid and, in smaller quantities, formic acid ${ }^{[22]}$. This is a well-known fact, as evidenced in old wood shelves in museums.

There are several bibliographic references reporting the presence of propionic acid as a result of the methanogenic degradation of hydrocarbons, caused by bacteria such as Bacteroides fragilis, Clostridium paraputrificum, Lactobacillus, Nitrosomonus, Propionibacterium freudenreichi and Propionibacterium acidipropionici. Clostridium paraputrificum degrades soils by anaerobic processes, producing propionic acid, acetic acid and hydrogen. Lactobacillus decomposes lactic acid and Propionibacterium acidipropionici produces propionic acid by anaerobic degradation of lactose, acetate, piruvate or succinate. The latter is also used as a reactant in the production of Swiss cheeses (Emmental cheese), along with other bacteria that produce lactic acid ${ }^{[57]}$.

\subsection{Chemical and photochemical generation of carboxylic acids}

Acetic acid may be generated by one of the following processes: catalytic reactions of ethylene (in the presence of nitric $\left(\mathrm{HNO}_{3}\right)$ acid), electrical discharge at low pressure, direct carboxylation of methane $\left(\mathrm{CH}_{4}\right)$ and carbon monoxide (CO) in the presence of catalysts, photolysis of butyric acid or ozonolysis of monoterpenes $^{[58]}$. 
ANT-NEST CORROSION OF COPPER TUBING IN AIR-CONDITIONING UNITS CORROSIÓN POR NIDO DE HORMIGAS DE TUBOS DE COBRE UTILIZADOS EN SISTEMAS DE AIRE ACONDICIONADO

Table II. Biogenic emissions of low molecular weight carboxylic acid $\left(10^{9} \mathrm{~mol} / \mathrm{cm}^{2} \mathrm{~s}^{1}\right)$.

Tabla II. Emisiones biogénicas de ácidos carboxílicos de bajo peso molecular $\left(10^{9} \mathrm{~mol} / \mathrm{cm}^{2} \mathrm{~s}^{1}\right)$.

\begin{tabular}{ccccc}
\hline Place & Formic acid & Acetic acid & Propionic acid & Reference \\
\hline Amazonia, Brazil & 4.6 & 99.8 & - & {$[52]$} \\
Mayombe, Kenya & 3.1 & 7.8 & 8.4 & {$[50]$} \\
\hline
\end{tabular}

During the ozonolysis of olefins (such as isoprene and pinene), carboxylic acids can be produced by a mechanism that involves the formation of an ozonide which quickly decomposes into highly energetic carbonyls and Criegee birradicals ${ }^{[4]}$. Isomerisation of the latter produces the corresponding carboxylic acid. Formic acid may be expected to form in the gaseous phase from the reaction of ethene, propene, 1pentene, 1-butene, 1-hexene, iso-butene, 3-methyl 1pentene, cyclohexene, 1,3 butadiene and 2-methyl 1,3 butadiene with ozone. Furthermore, also in the gaseous phase, acetic acid forms from the reaction of ozone with propene, 2-butene, 2-pentene and 2-methyl 2 -butene ${ }^{[58]}$. Formic acid can be originated by the pyrolysis of ethyleneglycol or by hydrolysis of chlorinated organic solvents ${ }^{[22]}$.

It is known that an important source of acetic acid in the atmosphere, is the reaction of the acetylperoxyl radical $\left(\mathrm{CH}_{3} \mathrm{CO}\left(\mathrm{OO}^{\circ}\right)\right)$ in environments with low $\mathrm{NO}_{x}$ contents (clean tropospheres), especially at night ${ }^{[44,59}$ and 60$]$. The proposed reaction is:

$$
\begin{gathered}
\mathrm{CH}_{3} \mathrm{CO}\left(\mathrm{OO}^{\circ}\right)+\mathrm{HOO} \rightarrow \mathrm{CH}_{3} \mathrm{COOH}+\mathrm{O}_{3} \\
\mathrm{CH}_{3} \mathrm{CO}\left(\mathrm{OO}^{\circ}\right)+\mathrm{CH}_{3} \mathrm{OO}^{\circ} \rightarrow \\
\mathrm{CH}_{3} \mathrm{COOH}+\mathrm{HCOH}+\mathrm{O}_{3}
\end{gathered}
$$

In a similar way, formic acid can be obtained from the reaction in the atmosphere of the hydroxymethyl peroxyl radical $\left(\mathrm{HOCH}_{2} \mathrm{OO}^{\bullet}\right)^{[44]}$. In this process, formaldehyde reacts with $\mathrm{HOO}$ and forms $\mathrm{HOOCH}_{2} \mathrm{O}^{\circ}$ as a by-product, which rapidly isomerises to form the hydroxymethyl peroxyl radical. This radical reacts with HOO to produce formic acid:

$$
\begin{gathered}
\mathrm{HCHO}+\mathrm{HOO} \rightarrow \mathrm{HOOCH}_{2} \mathrm{O}^{\bullet} \\
\rightarrow \mathrm{HOCH}_{2} \mathrm{OO}^{\circ} \\
\mathrm{HOCH}_{2} \mathrm{OO}+\mathrm{HOO} \rightarrow \\
\mathrm{HCOOH}^{\circ} \mathrm{H}_{2} \mathrm{O}+\mathrm{O}_{2}
\end{gathered}
$$

Following the mechanism described by Carter ${ }^{[59]}$, propionic acid can be obtained from the respective peroxyacyl radical, according to the reaction:

$$
\begin{gathered}
\mathrm{CH}_{3} \mathrm{CH}_{2} \mathrm{CO}\left(\mathrm{OO}^{\circ}\right)+\mathrm{HOO} \rightarrow \\
\mathrm{CH}_{3} \mathrm{CH}_{2} \mathrm{COOH}+\mathrm{O}_{3}
\end{gathered}
$$

\section{Industrial emissions of carboxylic acids}

Industrial emissions of carboxylic acid are produced by plants processing biological materials, such as food, paper, wood, etc. ${ }^{[17,61 \text { and } 62]}$. Acetic acid vapours are found in several industrial atmospheres. Vinegar is one important source of acetic acid vapours in food processing plants. These vapours are also the result of the decomposition of raw materials in the paper industry.

Propionic acid is found in everyday consumer products, such as milk, butter or cheese, especially after their fermentation starts. Propionic acid is widely used as a preservative of animal feed (soya bean, corn, etc.) and wood. It is also employed as a raw material for the production of polymeric resins, fungicides, antibiotics, paint removers, glues, inks, and products used in aluminium anodising processes ${ }^{[63}$ and 64].

Carboxylic acids can also be emitted by the decomposition of paint formulations and packing materials. Phenolic resins can emit formaldehyde, which may oxidise to formic acid in the presence of metallic surfaces. Plastics of the amino type (found in certain adhesives and porous materials) can emit formic acid, formaldehyde, ammonia and catalytic acids ${ }^{[65]}$. Similarly, plywood type construction materials emit acetic, formic acid and formaldehyde in humid and hot environments. Polyvinyl acetate (used as a binder in several industrial products) and cellulose acetate emit acetic acid in conditions that favour the hydrolysis of these compounds. Table III shows carboxylic acid emissions from different types of engines and fuels $^{[29,49,51 \text { and 66-68]. }}$.

\subsection{Copper corrosion in outdoor and indoor atmospheres originated by organic acids}

Metal corrosion caused by organic acids is a phenomenon that has long been observed. This type of corro- 
Table III. Carboxylic acid emissions from different types of engines and fuels.

Tabla III. Emisión de ácidos carboxílicos procedentes de diferentes tipos de motores y combustibles.

\begin{tabular}{cccccc}
\hline Engin. type/Fuel & Igniti./Nat.Gas & Igniti./Gasolin & Igniti./Gasolin & Ignit./Gasolin & Compre./Die. \\
\hline Formic acid & $0-0.6 \mathrm{ppm}$ & $9.3 \mathrm{ppb}$ & $0.14-0.5 \mathrm{ppm}$ & $0.1-15 \mathrm{ppm}$ & $2-6 \mathrm{ppm}$ \\
Acetic acid & - & $31.81 \mathrm{ppb}$ & $0.3-1.1$ & $2-40 \mathrm{ppm}$ & $4-6 \mathrm{ppm}$ \\
Propionic acid & - & $1.2 \mathrm{ppb}$ & - & $0.5-80 \mathrm{ppm}$ & $0.4-3 \mathrm{ppm}$ \\
Reference & {$[51]$} & {$[49]$} & {$[29]$} & {$[51]$} & {$[51]$} \\
\hline
\end{tabular}

sion can occur in both outdoor and indoor atmospheres. In outdoor atmosphere it is characterised by a high aggressive ion concentration and the presence of solid particles, associated with an alternating sequence of dry and wet periods, seasonal variations, variable winds hitting the metallic surface, the important influence of extreme temperature, radiation and RH conditions, drop deposition from dew, or the depositions of foreign bodies, such as bird droppings. This is the characteristic environment of sculptural works or exposed outdoor structures.

On the other hand, in indoor atmospheres, which are moderately more benign, there is a lesser likelihood of extreme temperature, radiation or RH variations. As the wind speed is lower, the amount of solid particles is smaller; nevertheless, these can contain considerable organic compound concentrations. In addition to the normal contents of these gaseous pollutant agents in the atmospheric air, certain building materials like those mentioned earlier can emit carboxylic acids. Organic molecules can also be deposited on the metallic surfaces from particles and aerosols in the atmosphere. Therefore, indoor metallic corrosion products can be expected to contain important amounts of organic compounds. As a consequence they will be different to the corrosion products obtained in outdoors environments. The hydrolysis of hemicellulose in old wooden boxes, mentioned above, can produce concentrations of up to $100 \mathrm{ppb}$ of acetic acid. Concentrations of up to 10 ppm of acetic acid have been measured in enclosed spaces such as cupboards, cabinets and display cases that contain acidemitting organic products ${ }^{[69]}$.

Consequently, organic acids can cause corrosion on several metals, especially zinc, nickel, lead, iron, cadmium and copper. Aluminium and tin are very resistant to attack by organic acids ${ }^{[70]}$. For metals exposed to vapours of solutions containing $1 \%$ acetic acid and nearly $100 \% \mathrm{RH}$, the following ranking of corrosion rates has been determined ${ }^{[70]}$ : steel $>\mathrm{Mg}_{8} \mathrm{Al}_{0.4} \mathrm{Zn}$ $>$ zinc $>$ cadmium $>$ copper $>\mathrm{Mg}_{3} \mathrm{AlZn}>$ brass $>$ nickel $>>$ aluminium $>>$ tin.

Vernon ${ }^{[71]}$ reported the deterioration of copper structures exposed in urban atmospheres to the pre- sence of organic acids for long periods and concluded that the attack in the presence of acetic acid was more vigorous than in the presence of formic acid.

Fukuda et al. ${ }^{[72]}$ confirms the existence of copper carboxylates in specimens exposed to indoor environments in cities of south-east Asia. On the other hand, copper acetates have been detected as part of the corrosion products on surfaces exposed to indoor atmospheres $^{[41 \text { and } 73] \text {. }}$

The corrosion products obtained on copper specimens after one year of exposure in a highly contaminated urban atmosphere showed $4.7 \mathrm{mM} / \mathrm{cm}^{2}$ of acetate, while the average acetate content in the rainwater was $18.6 \mu \mathrm{m}^{[74]}$. In other studies performed with copper specimens using acetic acid permeation tubes in a flowing gas mixing chamber containing up to 200 ppb level of contaminant, the thickness of the corrosion products increased with the RH and the acetic acid concentration $^{[74]}$.

According to the results of López-Delgado et al. ${ }^{[17]}$, Bastidas et al.$^{[18]}$, Echavarría et al. ${ }^{[19}$ and 75$]$ and Cano et $a l .{ }^{[20]}$, for copper specimens exposed to organic vapours at $100 \% \mathrm{RH}$ and a contaminant level in the range of 10 to $300 \mathrm{ppm}$, the relative aggressiveness of these acids is (from high to low): acetic $>$ formic $>$ butyric $>$ propionic.

\section{ANT-NEST CORROSION OF COPPER TUBES}

Fig. 9 shows a SEM micrograph of the inner surface of a corroded copper tube used in an air-conditioning unit after two months in service. Pits can be observed with the typical shape of ant-nest corrosion, showing some microscopic caverns connected by tunnels.

Fig. 10 depicts the EDX (energy dispersive X-ray) spectrum from a pit shown in Fig. 9. Copper, silicon, sulphur, chloride and potassium signals can be observed. The chloride ion may arise from the chemical treatment of the copper tubes during manufacturing their process. Chloride has a harmful effect on copper and its alloys, and in the particular case of bronze it causes 'bronze disease', characterised by the formation 


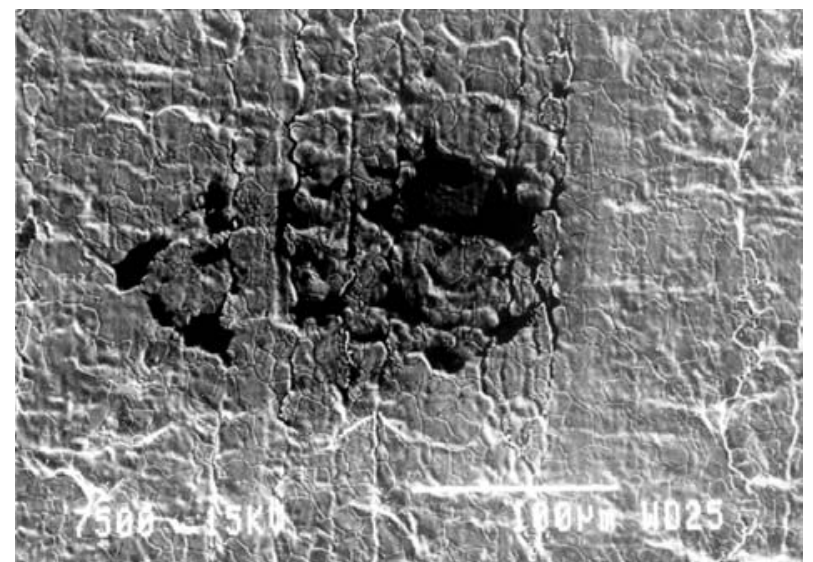

Figure 9. SEM micrograph of a corroded copper tube inner surface.

Figura 9. Micrografías de SEM de tubos de cobre atacados por la cara interna.

of atacamite $\left(\mathrm{CuCl}_{3} \cdot 3 \mathrm{Cu}(\mathrm{OH})_{2}\right)^{[76]}$. Sulphur also causes pitting corrosion on copper. This element may be present as a contaminant in the chemical products used in the cleaning treatments of copper tubes.

Fig. 11 shows a high resolution XPS spectrum of the inner surface of a corroded copper tube. The peaks of $\mathrm{Cu} 2 \mathrm{p}_{3 / 2}(\sim 932.5 \mathrm{eV})$ and Auger Cu LMM ( 337.0 eV) (see inset) can be observed. The intense shakeup satellite on the highest binding energy (BE) side of the main $\mathrm{Cu} 2 \mathrm{p}$ peak indicates that the copper is found in an oxidation state (II). The shoulder indicated by the arrow signals the presence of tenorite and/or $\mathrm{Cu}(\mathrm{OH})_{2}$. The Auger Cu LMM peak defined at $\sim 337.0 \mathrm{eV}$ indicates the presence of copper(I $)^{[77]}$.

Fig. 12 depicts deconvolution of the high resolution XPS spectrum of $\mathrm{C} 1 \mathrm{~s}$ of the inner surface of a corroded copper tube. Four components can be observed, located at $\sim 284.8 \mathrm{eV}$ attributed to hydrocarbon (C-C), at $\sim 286.5 \mathrm{eV}$ as ether (C-O-C), at $\sim 288.0 \mathrm{eV}$ as acetone $(>\mathrm{C}=\mathrm{O})$, and at $\sim 289.0 \mathrm{eV}$ as acid $(\mathrm{OH}>\mathrm{C}=\mathrm{O})$. The existence of the latter component may be attributed to the presence of organic acids such as formic, acetic and propionic in the corroded copper tube. Carboxylic acids may result from the hydrolysis of the self-evaporating lubricant oils. Likewise, the ether and acetone components may be caused by organic acids originated by the detergent used in the cleaning process.

A possible mechanism of ant-nest corrosion is described as follows ${ }^{[11}$ and ${ }^{18]}$. Copper is oxidised and dissolved according to the reaction: $\mathrm{Cu} \rightarrow \mathrm{Cu}^{+}+\mathrm{e}^{-}$. In the presence of an organic acid (e.g. formic acid) an unstable cuprous formate is formed:

$$
\begin{gathered}
\mathrm{Cu}^{+}+\mathrm{HCOO}^{-}+2 \mathrm{H}_{2} \mathrm{O} \rightarrow \\
\mathrm{Cu}(\mathrm{HCOO}) \cdot 2 \mathrm{H}_{2} \mathrm{O}
\end{gathered}
$$

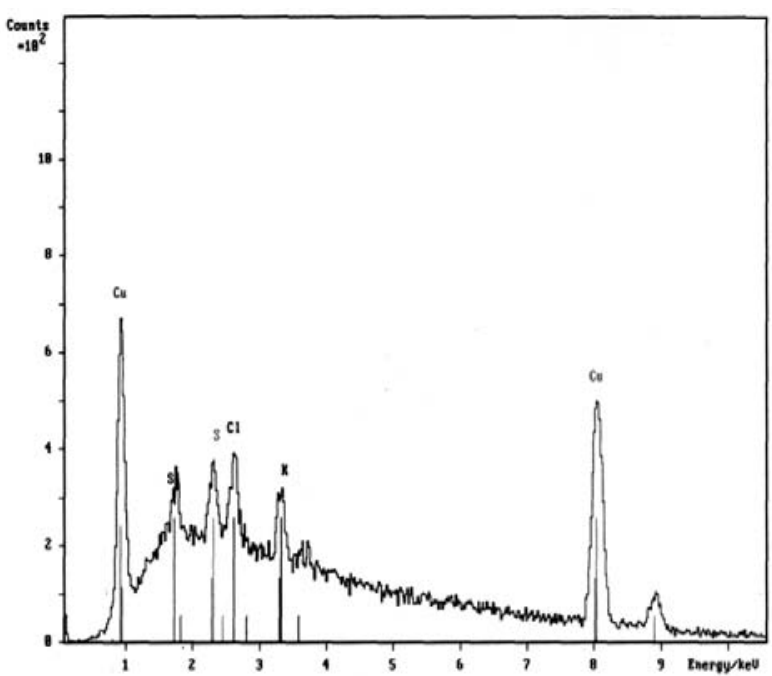

Figure 10. EDX spectrum of the corroded copper shown in Fig. 9.

Figura 10. Espectro EDX de los tubos de cobre de la Fig. 9.

The cuprous formate is oxidised to form cupric formate and cuprite, according to the autocatalytic reaction:

$$
\begin{gathered}
4 \mathrm{Cu}(\mathrm{HCOO}) \cdot 2 \mathrm{H}_{2} \mathrm{O}+{ }^{1} \mathrm{I}_{2} \mathrm{O}_{2} \rightarrow \\
2 \mathrm{Cu}(\mathrm{HCOO})_{2} \cdot 2 \mathrm{H}_{2} \mathrm{O}+\mathrm{Cu}_{2} \mathrm{O}+4 \mathrm{H}_{2} \mathrm{O} \\
\downarrow \uparrow \\
4 \mathrm{Cu}(\mathrm{HCOO}) \cdot 2 \mathrm{H}_{2} \mathrm{O} \leftarrow 2 \mathrm{Cu}(\mathrm{HCOO})_{2} \\
2 \mathrm{H}_{2} \mathrm{O}+2 \mathrm{Cu}+4 \mathrm{H}_{2} \mathrm{O}
\end{gathered}
$$

causing the formation of pits and random interconnected tunnels which progress rapidly into the tube wall. The oxygen reduction is mainly the cathodic reaction $\left(1 / 2 \mathrm{O}_{2}+\mathrm{H}_{2} \mathrm{O}+2 \mathrm{e}^{-} \rightarrow 2 \mathrm{OH}^{-}\right)$.

\section{MECHANISM OF INITIATION OF COPPER ANT-NEST CORROSION}

Ant-nest corrosion is a type of local corrosion similar to pitting corrosion and is explained by the combination of microanodes causing anodic dissolution and a microcathode causing a reduction reaction in the presence of corrosion-promoting substances. Since this type of corrosion invariably occurs in a wet atmosphere, the anodic reaction involves dissolution of copper as copper ions in a trace amount of water. The cathodic reaction is believed to be an oxygen reduction reaction. As corrosive media, decomposition products of organic chlorine compounds and organic carboxylic acids are predicted to be available, together with fluoride ions from lubricants, borofluorides used in brazing of copper tubes, and freon gas. These substances are divided into those adhering to the surface 


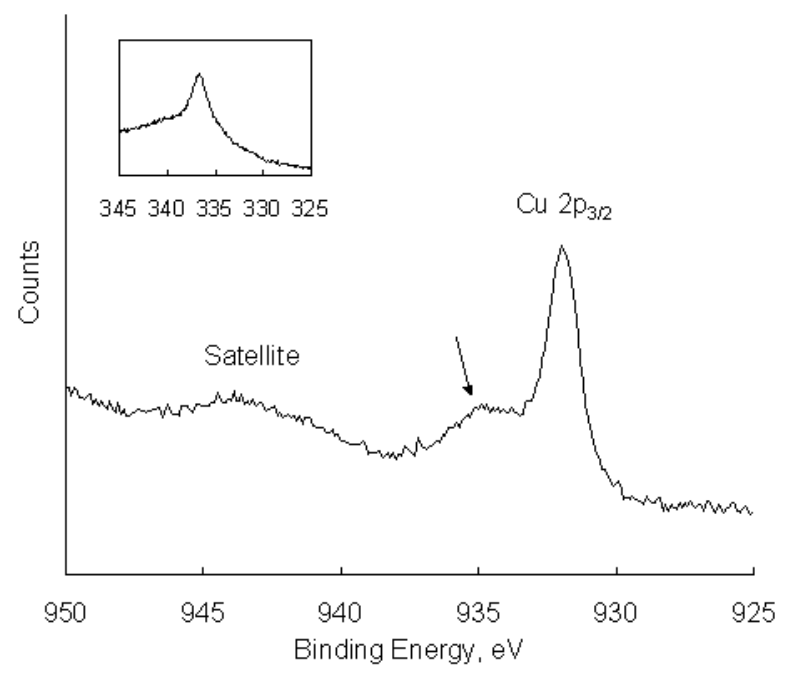

Figure 11. High resolution Cu 2p XPS spectra of a corroded copper tube inner surface. Auger peak Cu LMM in the inset spectrum.

Figura 11. Espectro XPS de alta resolución del Cu 2p de un tubo de cobre corroído por la cara interna. Pico Auger Cu LMM en el espectro del recuadro pequeño.

during the manufacturing process and those adsorbed from the environment during use. Carboxylic acids belong to the latter category ${ }^{[1-7}$ and $\left.78-84\right]$.

In a solution containing a trace amount of carboxylic acid, processes leading to copper dissolution and the formation of copper oxides progress simultaneously. For example, in an oxygen-saturated $1 \times 10^{-3} \mathrm{M}$ formic acid solution at $25^{\circ} \mathrm{C}$, the copper surface dissolves while turning grey. Formicary corrosion is considered to take place in these conditions. It may well progress by a process similar to bronze disease $\mathrm{e}^{[8-14}$ and 82-89].

The surface of copper tubes is usually covered by a thin protective cuprous oxide film. However, weaknesses such as discontinuities in the oxide film are eroded by the organic carboxylic acid present:

$$
\mathrm{Cu} \rightarrow \mathrm{Cu}^{+}+\mathrm{e}^{-}
$$

Carboxylic acid ions and copper ions form a copper complex:

$$
\mathrm{Cu}^{+}+(\mathrm{ORG})^{-} \rightarrow \mathrm{Cu}(\mathrm{ORG})
$$

Where, $(\mathrm{ORG})^{-}$is $\mathrm{HCOO}^{-}, \mathrm{CH}_{3} \mathrm{COO}^{-}, \mathrm{CH}_{3} \mathrm{CH}_{2} \mathrm{COO}^{-}$, $\mathrm{CH}_{3}\left(\mathrm{CH}_{2}\right)_{2} \mathrm{COO}^{-}$, etc.

The copper complex is oxidised by oxygen to form a cupric complex of cuprite and a complex of $\mathrm{Cu}^{2+}$ with the carboxylic acid:

$$
4 \mathrm{Cu}(\mathrm{ORG})+1 /{ }_{2} \mathrm{O}_{2} \rightarrow \mathrm{Cu}_{2} \mathrm{O}+2 \mathrm{Cu}(\mathrm{ORG})_{2}
$$

with microcracks being initiated at weaknesses in the corrosion pit wall under a wedging effect due to the volume expansion associated with the formation of

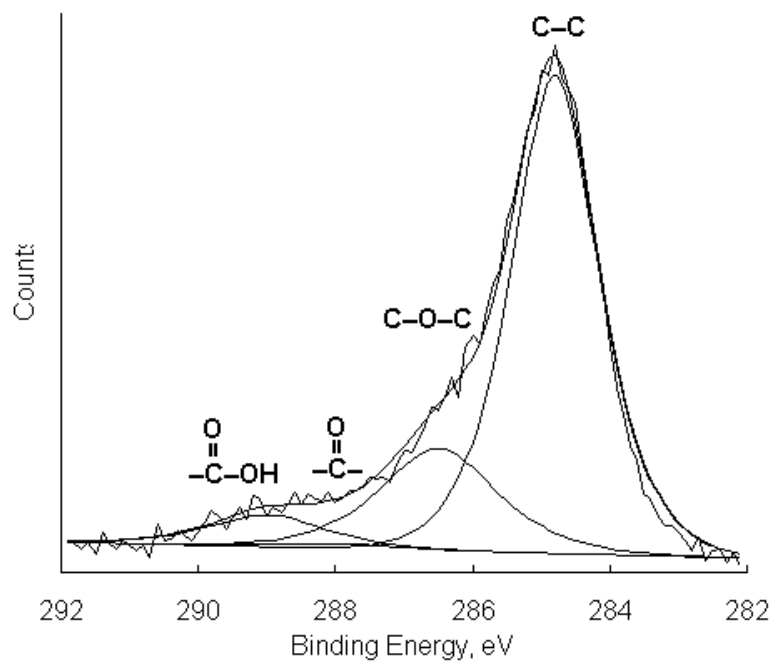

Figure 12. High resolution C 1s XPS spectrum of a corroded copper tube inner surface.

Figura 12. Espectro XPS de alta resolución del C 1s de un tubo de cobre corroído por la cara interna.

cuprite. Cuprite could also be produced by the anodic reaction:

$$
2 \mathrm{Cu}+2 \mathrm{OH}^{-} \rightarrow \mathrm{Cu}_{2} \mathrm{O}+\mathrm{H}_{2} \mathrm{O}+2 \mathrm{e}^{-}
$$

The cathodic reaction is (as indicated above):

$$
1 / 2 \mathrm{O}_{2}+\mathrm{H}^{+}+2 \mathrm{e}^{-} \rightarrow \mathrm{OH}^{-}
$$

The hydroxyl ions $\left(\mathrm{OH}^{-}\right)$formed at the cathode migrate and diffuse toward the anode to form $\mathrm{Cu}_{2} \mathrm{O}$. The cuprite could produce cracks at weak points in the pits because it has a larger volume, given rise to a plug effect. In a further anodic reaction, $\mathrm{Cu}(\mathrm{ORG})_{2}$ reacts with copper on the freshly $\left(\mathrm{Cu}^{0}\right)$ formed surface to give $\mathrm{Cu}^{+}$from:

$$
\mathrm{Cu}(\mathrm{ORG})_{2}+\mathrm{Cu}^{0} \rightarrow 2 \mathrm{Cu}(\mathrm{ORG})
$$

These reactions recur. Through the hydroxyl ions formed by the oxygen reduction which increases the $\mathrm{pH}$ inside the corrosion pits, cuprite decomposes the carboxylic acid complex, although pathways formed via cupric hydroxide may also be considered. The weakness inside the corrosion pits may well also imply the presence of grain boundaries with relatively high concentrations of trace impurities, such as iron and phosphorus, although erosion initiation is not necessarily confined to the grain boundaries. Even in a humid environment, the supply of water inside the corrosion pits is limited owing to their physical structure. The widths of the corrosion pathways are therefore also limited. Matsuoka et al. suggested that this type of corrosion is susceptible to the effect of capillary for$\mathrm{ces}^{[90]}$, and in fact the corrosion products or porous 
cuprite absorb the moisture by capillary forces which thus promote the process inside the corrosion pits, although capillary forces cannot be regarded as being the driving force of this type of corrosion. Since water in the process of condensation serves as the corrosion medium, the initiation of corrosion is not necessary confined to the direction of gravitation, and various sites both inside and outside the copper tubes may act as initiators. However, under a pumping effect due to repetitive high/low temperature cycles, oxygen readily infiltrates the corrosion pits. This oxygen oxidises the cuprous complex formed inside the corrosion pits and is also reduced on the cuprite surface inside the pits, so that corrosion is also promoted. Cathodic reduction reaction surfaces are therefore considered to be present not only on the outer surface, but also inside the corrosion pits. Microcracks in the cuprite formed inside the corrosion pits may well be accelerated by dry/wet atmospheric cycling and residual stresses in the copper tubes.

Very small droplets on the pit walls may carry the substances that promote corrosion. Oxygen may penetrate on account of pumping caused by heating and cooling cycles. Penetrating oxygen is consumed in the oxidation of $\mathrm{Cu}(\mathrm{ORG})$ and the cuprite on the wall.

The thickness of the copper tube walls where such corrosion is found ranges from $0.3 \mathrm{~mm}$ to $1.1 \mathrm{~mm}$, with a peak of around $0.5 \mathrm{~mm}$. Copper tubes suffering from ant nest corrosion appear to be mostly 'soft' copper (85\%). In order to establish effective measures against ant nest corrosion it is important to know where it begins. 34\% of cases begin on the inner surface, $60 \%$ on the outer surfaces, and $6 \%$ have unidentified starting points ${ }^{[80]}$

Copper tubes in this apparatus are classified into three categories: bent, straight, and soldered. 66\% of incidents occur in straight pipe parts. $31 \%$ in bent pipe parts, and only $3 \%$ in soldered parts. As such, the correlation between the occurrence of ant nest corrosion and the residual stresses introduced during bending does not seem to be of any particular significance.

The colour of the copper tube surface around antnest corrosion is usually reddish brown or black, typical of oxidised copper, although greenish blue discoloration is sometimes also found. Unlike in cases of copper tube pitting, the accumulation of voluminous corrosion products such as verdigris is not found around the opening of ant-nest corrosion pits.

A model based on the general atmospheric corrosion mechanism and which assumes the presence of an aqueous adlayer over the metal surface has been proposed in the bibliography ${ }^{[37,41,91]}$. It includes the formation of carboxylate-containing surface species and the concept of a proton- and ligand-induced dissolution mechanism. The aqueous adlayer produces surface hydroxyl bonds over the cuprite surface ge- nerated on copper, and the dominant electrochemical reactions are the above proposed equations (16) and (20). The hydroxyl bonds have ion exchange properties and can be replaced by ions present in the aqueous adlayer, such as protons $\left(\mathrm{H}^{+}\right)$or carboxylic acid ions: (ORG) ${ }^{-}$, which have been formed upon the dissociation of carboxylic acids $\left(\mathrm{HCOOH}, \mathrm{CH}_{3} \mathrm{COOH}\right.$, etc.) in the aqueous adlayer. The result is a ligand-induced dissolution triggered by the weakness of the surface metal atoms that participate in the ion exchange. Copper dissolves initially as cuprous ions, which may either react with liberated hydroxyl ions $\left(\mathrm{OH}^{-}\right)$ to form cuprous oxide, or may oxidise to cupric ions, react with carboxylate ions, and form copper carboxylate. As the dissolution process continues, copper carboxylate precipitates are formed and grow over localised points of the surface until they reach a critical size. The copper carboxylate may react with copper to reform the surface complex, as proposed in equation (21), thus creating conditions for more copper to be dissolved and more cuprous oxide and copper carboxylate to precipitate in the aqueous adlayer.

\section{CONCLUSIONS}

Total emissions of carboxylic acids ( $\mathrm{R}-\mathrm{COOH}, \mathrm{R}=\mathrm{H}$, $\mathrm{CH}_{3}, \mathrm{CH}_{3} \mathrm{CH}_{2}$, etc.) are at the same level as other pollutants, when total deposition is compared and taking into account the different forms of atmospheric precipitation (rain, snow, dew and fog).

Carboxylic acids can be generated mainly by anthropogenic or biogenic processes. They may also be produced by photochemical reactions of some organic substances.

Emissions of carboxylic acids can also be emitted by the decomposition of certain paint formulations, organic packing material, or the hydrolysis of hemicellulose (main constituent of wood). The latter phenomenon is especially important in airtight wooden cabinets and indoor environments.

Organic acids cause corrosion on copper specimens at $100 \% \mathrm{RH}$ and a contaminant level in the range of 10 to $300 \mathrm{ppm}$. The relative aggressiveness of these acids is (from high to low): acetic > formic $>$ butyric $>$ propionic.

The study of the patination process in outdoor environments reveals the existence of an organic cementant among the copper compounds (oxides and hydroxyanions, sulphates, chlorides, nitrates), which probably corresponds to a copper oxalate.

The pitting corrosion of copper tubes characterised using the SEM technique shows the typical behaviour of ant-nest corrosion, with microcaverns connected by tunnels, which causes a high level of attack in a short time. XPS and EDX techniques indicate the 
presence of organic acids, chloride and sulphur. The possible sources of these components are the different cleaning treatments applied to copper tubes during the manufacturing process of commercial air conditioning systems. All of these components are very aggressive even at low concentrations and cause pitting corrosion on copper.

\section{Acknowledgements}

The authors express their gratitude to the International Copper Association (ICA) Ltd. (New York) and to the Centre for Advanced Interdisciplinary Research in Materials (CIMAT) (Chile) for financial support under Project No. TEK-1023-9.

\section{REFERENCES}

[1] T. Notoya, Corros. Eng. 39 (1990) 353-362.

[2] T. Notoya, J. Mater. Sci. Lett. 10 (1991) 389-391.

[3] T. Notoya, Mater. Perform. 32 (5) (1993) 53-57.

[4] T. Notoya, Zairyo-to-Kankio (Corros. Eng.) 46 (1997) 731-735.

[5] T. Notoya in: Corrosion and Prevention 1997 , Australian Corrosion Association, Brisbane, Australia, (1997), paper 02.

[6] T. Notoya, J. Mater. Sci. Lett., 16 (1997) 1406-1409.

[7] G.J. Kelly, P. LepelaAr and T. Notoya, Process Corrosion and Prevention 2000, Australian Corrosion Association, Australia, (2000).

[8] S. SATO, J. Japan Copper Brass Research Association, No. 2 (2001).

[9] J.O. Edwards, R.I. Hamilton and J.B. Gilmour, Mater. Perform. 16 (1977) 18-20.

[10] E. Cano, J. Simancas, J.L. Polo, C.L. Torres, J.M. Bastidas and J. Alcolea, Mater. Corros. 50 (1999) 103-110.

[11] E. Cano, J.L. Polo, J.A. López-Caballero and J.M. Bastidas, Corros. Prev. Control 52 (2005) 56-58.

[12] P. ElliotT and R.A. CorbetT, Corrosion 99, NACE International, Houston, (1999), paper 342.

[13] T. Notoya, T. Hamamoto and K. Kawano, Sumitomo Light Metal Technical Reports 30 (1989) 914.

[14] R.A. CORBETT, Corrosion 2004, NACE International, Houston, (2004), paper 321.

[15] M. Ohanian, R. Caraballo, E.A. Dalchiele, G. GutNEO-CoBs, V. MarTínEZ-LuACES and E. Quagliata, Rev. Metal. Madrid 41 (2005) 175-185.

[16] I. Cañadas, D. Martínez, J. Rodríguez and J.M. Gallardo, Rev. Metal. Madrid Vol. Extr. (2005) 165-169.

[17] A. López-DElgado, E. CANO, J.M. BAstidas and F.A. LÓPEZ, J. Electrochem. Soc. 145 (1998) 4140-4147.
[18] J.M. Bastidas, A. López-Delgado, E. Cano, J.L. POLO and F.A. LÓPEZ, J. Electrochem. Soc., 147 (2000) 999-1005.

[19] A. Echavarría, A. Rueda, E. Cano, F. Echeverría, C. Arroyave and J.M. Bastidas, in: Proc. 15th Int. Corrosion Congress, Granada, Spain, (2002).

[20] E. Cano, E.M. Mora, H. AzCaraY and J.M. BastiDAS, J. Electrochem. Soc. 151 (2004) B207-B213.

[21] E. CANO, D.M. Bastidas, A. Echavarría, J. Simancas and E.M. MORA, 16th Int. Corrosion Congress, Beijing, China, (2005), paper 19-1.

[22] E. CANO, J.M. BASTIDAs, J.L. POlO and N. Mora, J. Electrochem. Soc. 148 (2001) B431-B437.

[23] E. CANO, M.F. LÓPEZ, J. Simancas and J.M. BASTiDAS, J. Electrochem. Soc. 148 (2001) E26-E30.

[24] E. Cano, C.L. Torres and J.M. Bastidas, Mater. Corros. 52 (2001) 667-676.

[25] A. López-Delgado, E. Cano, J.M. Bastidas and F.A. López, J. Mater. Sci. 36 (2001) 5203-5211.

[26] J.C. Galván, J.M. Bastidas and S. Feliu, Weld.J. 75 (1996) 366s-371s.

[27] E. Cano and J.M. Bastidas, Can. Metall. Q., 41 (2002) 327-336.

[28] J.M. BASTIDAS and E.M. MORA, Can. Metall. Q. 37 (1998) 57-65.

[29] A. López-Delgado, J.M. Bastidas, M.P. Alonso and F.A. LópeZ, J. Mater. Sci. Lett. 16 (1997) 776779.

[30] E. CANO and J.M. BAstidas, Afinidad 62 (2005) 492-497.

[31] T.E. Graedel, C. McCrory-Joy and J.P. Franey, J. Electrochem. Soc. 133 (1986) 452-453.

[32] A.J. Muller and C. MCCrory-Joy, Corros. Sci. 27 (1987) 695-701.

[33] T.E. Graedel, Atmospheric Chemical Compounds. Sources, Occurrence and Bioassay. Academic Press, Orlando, Fl. (1986).

[34] T.E. GRAEDEL, J. Electrochem. Soc. 133 (1986) 24762482.

[35] T.E. GRAEDEL, J. Electrochem. Soc., 141 (1994) 922927.

[36] T.E. GRAEDEL and C. LEYGRAF, J. Electrochem. Soc. 147 (2000) 1010-1014.

[37] C. Leygraf and T.E. Graedel, Atmospheric Corrosion, Wiley InterScience, Pennington, NY, (2000), p. 17.

[38] T.E. Graedel, K. Nassau and J.P. Franey, Corros, Sci. 27 (1987) 639-657.

[39] T.E. Graedel, Corros. Sci. 27 (1987) 741-769.

[40] K. Nassau, P.K. Gallagher, A.E. Miller and T.E. GraEdel, Corros. Sci. 27 (1987) 669-684.

[41] D. Peerson and C. Leygraf, J, Electrochem. Soc. 142 (1995) 1468-1477.

[42] A. Khwaja, Atmos. Environ. 29 (1995) 127-139.

[43] C.G. NOlTe, M.P. Fraser and G.R. CASs, Environ. Sci. Technol. 33 (1999) 540-545. 
ANT-NEST CORROSION OF COPPER TUBING IN AIR-CONDITIONING UNITS CORROSIÓN POR NIDO DE HORMIGAS DE TUBOS DE COBRE UTILIZADOS EN SISTEMAS DE AIRE ACONDICIONADO

[44] A. Chebbi and P. Carlier, Atmos. Environ. 30 (1996) 4233-4249.

[45] M.P. Alonso, Efecto de la Contaminación Atmosférica en las Esculturas de Bronce, PhD Thesis, Complutense University of Madrid, Madrid, (1994).

[46] H. FANG and X. JIA, Wat. Res., 33 (1999) 1791-1798.

[47] L. Black and G. Allen, Brit. Corros. J. 34 (1999) 192-197.

[48] I. Bridier, F. Caralp, H. Loriat, R. Lesclaux, B. VeGret, K.H. Becker, A. Reimer and F. ZABAL, J. Phys. Chem. 95 (1991) 3594-3600.

[49] K. KaWAmura and I.R. KaPlan, Atmos. Environ. 19 (1985) 1082-1086.

[50] J. Servant, G. Konadio, B. Cros and R. Delmas, J. Atmos. Chem. 12 (1991) 367-380.

[51] E. Zervas, X. Montagne and J. Lahaye, J. Air Waste Manage. 49 (1999) 1304-1314.

[52] M.O. Andreae, R.W. TAlBot and S.-M. Li, J. Geophys. Res. 92 (1987) 6635-6641.

[53] R. Atkinson, Atmos. Environ. 24A (1990) 1-41.

[54] N. Kumar, U.C. Kulshreshta, A. SAXENA, K.M. KuMARI and S.S. SRIVASTAVA, Atmos. Environ. B-Urb. 27 (1993) 87-91.

[55] H. Puxbaum, C. Rosenberg, M. Gregori, C. LanZERSTORFEr, E. Ober and W. Winiwarter, Atmos. Environ. 22 (1988) 2841-2850.

[56] T.E. Graedel, Corros. Sci. 27 (1987) 721-740.

[57] A. Echavarría, F. Echeverría, C. Arroyave, E. CANO and J.M. BASTIDAs, Corros. Rev. 21 (2004) 395402.

[58] S. Koch, R. Winterhalter, E. UhereK, A. Kolloff, P. Neeb and G.K. Moortgat, Atmos. Environ. 34 (2000) 4031-4042.

[59] W. CARTER, Atmos. Environ. 24A (1990) 481-518.

[60] P. Dagaut, T.J. Waluington, R. Liu and M.J. KuRYLO, Int. J. Chem. Kinet. 20 (1988) 331-338.

[61] D.M. Bastidas, P.P. GÓmez and E. CANO, Rev. Metal. Madrid 41 (2005) 98-106.

[62] M.I. Martín, F.A. López and F.J. Alguacil, Rev. Metal. Madrid 41 (2005) 292-298.

[63] E. CANo, Efecto de los Vapores de los Ácidos Acético y Fórmico en la Degradación y Patinado del Cobre, PhD Thesis, Complutense University of Madrid, Madrid, (2000).

[64] A. ECHAVARRÍA, Estudio del Mecanismo de Interacción Entre el Cobre Puro y los Vapores de Ácido Propiónico, PhD Thesis, University of Antioquia, Medellín, Colombia, (2004).

[65] D. KnotKová-Cermákova and J. Vleková, Brit, Corros.J. 6 (1971) 17-22.

[66] M. López, C. CAMURri, D. CORREDOR and J.A. JimeNEZ, Rev. Metal. Madrid 41 (2005) 313-318.

[67] O. Comineli, H. LuO, H.M. Liimatainen and L.P. Karjalainen, Rev. Metal. Madrid, Vol. Extr. (2005) 407-411.
[68] E. Donoso, A. Varschavsky and G. Díaz, Rev. Metal. Madrid Vol. Extr. (2005) 502-506.

[69] J. Tétreault and E. Stamatopoulou, Stud. Conserv. 42 (1997) 141-156.

[70] S.G. Clarke and E.E. Longhurst, J. Appl. Chem. 11 (1961) 435-443.

[71] W.H.J. Vernon, J. Chem. Soc. (1934) 1853-1859.

[72] Y. Fukuda, T. Fukushima, A. Sulaiman, I. MusaLAM, L.C. YAP, L. ChatimongKol, S. JudABOnG, A. PotjanaRT, O. KeOWKANGWAL, K. YOShIHARA and M. Tosa, J. Electrochem. Soc. 138 (1991) 1238-1243.

[73] B. Rosales, R. Vera and G. Moriena, Corros. Sci. 41 (1999) 625-651.

[74] H. Vilca and I.V. AOKI, Proc. Corrosion in Electronic Equipment, Campinas, Brazil, (2000).

[75] A. EChavarría, A. Rueda, E. CANO, F. EChEverría, C. Arroyave and J.M. Bastidas, J. Electrochem. Soc. 150 (2003) B140-B145.

[76] W.H.J. Vernon, Trans. Faraday Soc. 27 (1931) 255.

[77] S.K. CHAWLA, B.I. RicKETT, N. SANKABRAMAN and J.H. PAYER, Corros. Sci. 33 (1992) 1617.

[78] T. Notoya, Corros. Eng. 45 (1997) 319-321.

[79] T. Notoya, T. HАMAmoto and K. Kawano, Mater, Inform. Trans. Service 6 (1989) 1-13.

[80] G. Isobe, T. Inoue, K. Nagata, T. Notoya, H. BABa, F. Hidaka, M. Watanabe, T. Atsumi, K. MinaMOTO, M. KoDAIRA and F. TAKAgI, Corrosion Asia Proc. (1992), pp. 106-109.

[81] S. Yamauchi, K. Nagata, S. Sato and M. ShimoNO, J. Japan Copper and Brass Research Association 22 (1983) 132-140.

[82] T. Notoya, T. Ishikawa, T. Hamamoto, K. KawaNO, First Joint Conference on Corrosion, Finishing and Materials, A. Atrens, M.S. Pennisi, D.P. Schweinsberg, (Eds.), Queensland, (1989), pp. 565-573.

[83] T. НАмамото and M. Imai, Sumitomo Light Metal Technical Reports, 32 (1991) 243-249.

[84] T. Notoya, J. Univ. Sci. Tech. Beijin 6 (1999) 129132.

[85] K. Nagata and K. KaWANO, Sumitomo Light Metals Technical Reports 35 (1994) 28-35.

[86] H. BABA and T. KodAma, Corros. Eng. 44 (1995) 279-287.

[87] R.S. LENOX and P.A. HOUgh, ASHRAE.J. (1995) 5056.

[88] G. Tetley, M. Heidenreich and K. Smith, Air Conditioning, Heating Refrigeration News 30 (1988) $1-3$.

[89] R.A. CoRbett, P. ElLiotT, Corrosion 2000, NACE International, Houston, (2000), paper 646.

[90] H. Matsuoka, Y. Masunaga, S. Mitsumoto and H. SEKI, Corros. Eng. 36 (1987) 696-711.

[91] J. TidBlad and T.E. Graedel, Corros. Sci. 38 (1996) 2201-2224. 